\title{
PEMODELAN SISTEM KETENAGALISTRIKAN SKALA KECIL TERISOLASI MENGGUNAKAN JARING PETRI KONTINU BERWAKTU
}

\author{
Abdul Halim \\ Departemen Teknik Elektro, Fakultas Teknik, Universitas Indonesia \\ ahalim@ee.ui.ac.id
}

\begin{abstract}
Abstrak - Pemanfaatan sistem ketenagalistrikan skala kecil terisolasi untuk mendukung pasokan listrik akan terus meningkat. Sistem ini digunakan dengan berbagai tujuan khususnya untuk memasok kebutuhan listrik daerah terpencil. Untuk mendapatkan kinerja sistem yang bagus, sistem ini membutuhkan mekanisme pengaturan yang mengkoordinasikan komponen-komponen sistem. Mekanisme ini sering diistilahkan dengan sistem manajemen energi. Untuk mengembangkan sistem manajemen energi, umumnya para peneliti menggunakan model matematik sistem ketenagalistrikan. Kompleksitas dan kinerja sistem manajemen energi sangat bergantung pada model matematika tersebut. Dalam penelitian ini, model matematik sistem ketenagalistrikan akan diturunkan dengan menggunakan model jaring petri sebagai salah satu jenis model kejadian diskrit. Beberapa jenis jaring petri sudah digunakan dalam merancang sistem manajemen energi, tetapi penerapan jaring petri jenis kontinu berwaktu (Timed Continuous Petri Net/TCPN) yang dikembangkan oleh J.Julvez dkk. belum dipublikasikan. Dalam penelitian ini, model TCPN sistem ketenagalistrikan terisolasi yang dikembangkan disimulasikan dengan menggunakan perangkat lunak SimHPN. Hasil simulasi memperlihatkan bahwa model yang dikembangkan valid. Meskipun model baru diterapkan pada sistem yang sederhana, model ini dapat dikembangkan untuk sistem yang lebih kompleks.
\end{abstract}

Kata Kunci : Sistem Ketenagalistrikan Kecil Terisolasi, Model Jaring Petri Kontinu Berwaktu, Sistem
Majemen Energi

Abstract - Utilization of isolated small-scale electricity system for supporting power supplies will continue to rise. This system is used for various purposes, particularly to supply the electricity needs of remote areas. To obtain a good performance of the system, the system requires regulatory mechanisms that coordinate system components. This mechanism is often called as energy management system. To develop an energy management system, generally the researchers used a mathematical model of the electricity system. The complexity and performance of the energy management system is very dependent on the mathematical model. In this study, a mathematical model of the electricity system will be deployed using Petri Net Model as a kind of discrete-event model. Some types of Petri nets have been used in designing an energy management system, however the implementation of Timed Continuous Petri Net (TCPN) developed by J.Julvez et al. not yet published. In this study, TCPN model for isolated small-scale electricity system developed is simulated using software called SimHPN. Our simulation results show that the developed model is valid. Although the new model is applied to a simple system, this model can be developed for more complex systems

Keywords : Isolated Small-Scale Electricity System, Timed Continuous Petri Net, Energy Management System

Copyright $\odot 2016$ JNTE. All rights reserved

\section{PENDAhULUAN}

Kebutuhan energi listrik nasional terus meningkat. Pemerintah memperkirakan dalam kurun waktu 10 tahun ke depan kenaikannya mencapai 9,9\%[1]. Tidak mudah bagi Pemerintah untuk memenuhinya. Keterbatasan dana dan infrastruktur ketenagalistrikan menjadi masalah besar. Masalah infrastruktur ini semakin menantang khususnya di wilayahwilayah terpencil seperti di pulau-pulau dan daerah perbatasan. Selain itu terbatasnya cadangan energi fosil dapat menjadi masalah juga, tetapi Indonesia memiliki potensi energi terbarukan yang dapat membantu menopang pasokan listrik dalam negeri. Potensi energi 
surya, panas bumi, biomassa, angin dan sampah direncanakan terus dimanfaatkan[2].

Permasalahan yang hampir sama juga dihadapi oleh banyak negara di dunia khususnya negara-negara berkembang. Solusi teknologi telah diberikan oleh para peneliti dan industri antara lain melalui pemanfaatan teknologi pembangkit listrik energi terbarukan, teknologi elektronika daya, teknologi informasi dan komputasi yang diintegrasikan dalam sistem ketenagalistrikan skala mini, mikro atau yang lebih kecil [3],[4]. Dengan teknologi yang sama khususnya negara-negara maju memanfaatkannya dalam rangka mengurangi ketergantungan terhadap energi fosil dan mengurangi dampak lingkungan. Sistem ketenagalistrikan ini dapat beroperasi secara terisolasi atau terhubung dengan jaringan listrik utama [5].

Teknologi sistem ketenagalistrikan skala kecil (mini atau mikro) sudah diterapkan dan pemanfaatannya akan semakin meningkat. Seiring dengan peningkatan pemanfaatan dan kompleksitas komponen, diperlukan teknologi pengaturan sistem yang lebih baik, yaitu pengaturan pada tingkat lokal seperti pengaturan (controller) pada pembangkit listrik atau inverter, maupun pengaturan pada level yang lebih atas (supervisory) yang berfungsi mengkoordinasikan komponen-kompenen dalam sistem. Pengatur supervisi secara umum diistilahkan dengan sistem manajemen energi (Energy Management System/EMS)[6][7].

Tuntutan fungsi EMS akan semakin meningkat seiring dengan semakin banyak dan beragamnya komponen dalam sistem ketenagalistrikan skala kecil yang terhubung termasuk di dalamnya beban listrik AC maupun DC. Seperti umumnya metodologi dalam perancangan sistem pengaturan, perancangan EMS membutuhkan model sistem. Model matematik komponen sistem (model matematik battery, PV, wind turbine dll) umum digunakan. Tetapi dalam beberapa tahun terakhir dengan berkembangnya model kejadian diskrit(Discrete Event Model), model ini mulai digunakan dalam perancangan EMS [8][9][10]. Dalam tulisan ini, jaring petri kontinu berwaktu (Timed Continuous Petri Net/TCPN) sebagai salah satu jenis model kejadian diskrit akan diterapkan untuk memodelkan aliran energi listrik dalam sistem ketenagalistrikan skala kecil terisolasi. Model yang dikembangkan masih terbatas untuk sistem yang sederhana. Tetapi model ini dapat dikembangkan untuk sistem yang lebih kompleks. Validasi model ini dilakukan melalui simulasi menggunakan perangkat SimHPN[11].

\section{TINJAUAN PUSTAKA}

Dalam bagian ini akan dijelaskan tentang sistem ketenagalistrikan skala kecil terisolasi dan model jaring petri kontinu berwaktu.

\subsection{Sistem Ketenagalistrikan Skala Kecil Terisolasi \\ Komponen sistem ketenagalistrikan skala} kecil terisolasi dapat terdiri dari komponenkomponen sumber listrik DC, sumber listrik AC, konverter DC-DC, sistem penyimpan listrik, beban listrik DC, beban listrik ACS dan bidirectional inverter. Komponen-komponen ini diintegrasikan dengan menggunakan sistem majamen energi. Ilustrasi sistem diperlihatkan dalam Gambar 1. Dalam gambar ini, informasi kejadian setiap komponen yang signifikan dideteksi (event detection). Selanjutnya kejadian-kejadian tersebut diolah agar sistem dapat bekerja secara optimal. Hasil olahan data kejadian diumpan-balikkan ke sistem berupa perintah pembukaan/penutupan saklar atau pengaturan titik operasi komponen tertentu.

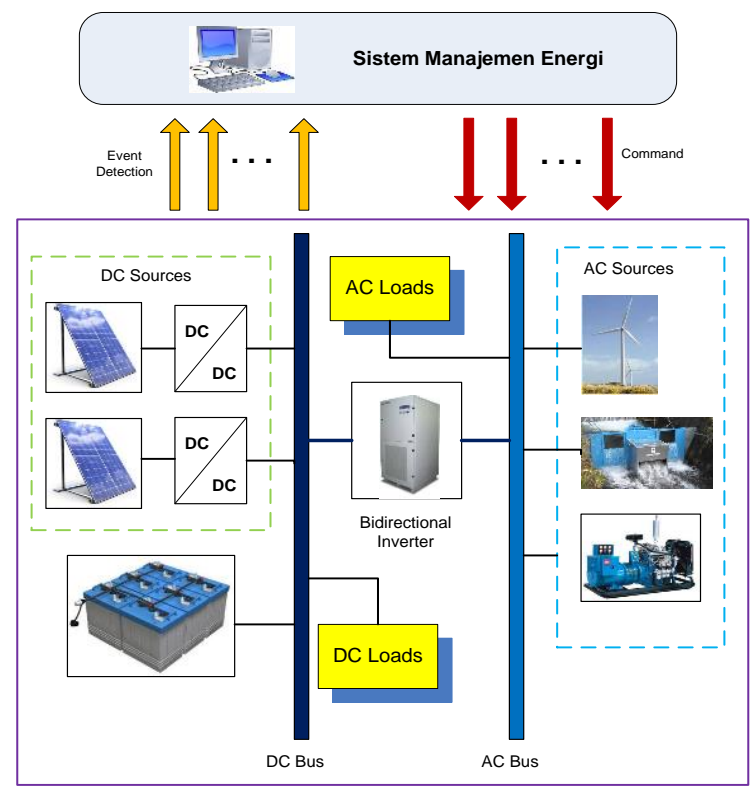

Gambar 1. Ilustrasi Sistem Ketenagalistrikan Skala Kecil 


\subsection{Jaring Petri Net Dasar}

Jaring Petri (Petri Net) adalah suatu metode pemodelan sistem kejadian diskrit (Discrete Event System) yang dikembangkan pertama kali oleh Carl Adam Petri pada tahun 1962. Metode ini sudah banyak diaplikasikan di berbagai bidang seperti bidang industri manufaktur, telekomunikasi, energi dan transportasi. Khusus di bidang transportasi A.Halim dkk telah menerapkan model jaring petri kontinu berwaktu untuk memodelkan aliran lalu lintas kendaraan bermotor di jalan raya[12][13][14].

Model jaring petri memiliki keunggulan dibandingkan dengan model kejadian diskrit yang lain seperti automata. Sejumlah keunggulan yang dimiliki antara lain adalah dapat merepresentasikan kondisi sistem yang beragam seperti sistem yang bekerja secara paralel, sinkron dan konflik[15].

Jaring petri dasar ditampilkan secara grafik seperti pada Gambar 2. Dalam gambar ini bentuk lingkaran disebut place, bentuk lingkaran kecil hitam disebut token, garis tegak lurus disebut transisi, dan tanda panah disebut arc. Makna dari masing-masing simbol dapat beragam sesuai dengan sistem yang dimodelkan. Dalam penelitian ini token dalam place tertentu berarti jumlah energi atau kondisi pengoperasian komponen sistem ketenagalistrikan.

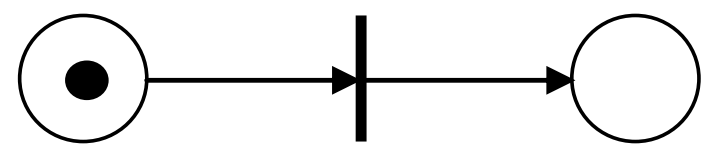

Gambar 2. Jaring Petri Dasar

\subsection{Jaring Petri Kontinu Berwaktu}

Dari model dasar yang dikembangkan oleh Carl Adam Petri seperti pada Gambar 2, dikembangkan beragam jenis jaring petri, salah satunya adalah Jaring Petri Kontinu Berwaktu (Timed Continuous Petri Net/TCPN). Ada banyak jenis TCPN, salah satunya yang dikembangkan oleh Julvez dkk [16].

Untuk membangun jaring petri kontinu berwaktu, perlu didefinisikan istilah-istilah berikut:

Struktur jaring petri kontinu $\mathcal{N}$ terbentuk dari 4 (empat) komponen utama, yaitu : $\mathcal{N}=\langle\boldsymbol{P}, \boldsymbol{T}, \boldsymbol{P r} \boldsymbol{e}, \boldsymbol{P o s t}\rangle$ dimana $P$ adalah himpunan terbatas semua place $p, \quad P=\left\{p_{1}, p_{2}, \cdots, p_{n}\right\}$ dengan $n>0, T$ adalah himpunan transisi $t$,
$T=\left\{t_{1}, t_{2}, \cdots, t_{m}\right\}$ dengan $m>0, \quad$ Pre adalah matriks pra-insiden, yaitu matriks himpunan bobot dari setiap anak panah dari place $p$ ke transisi $t$. Post adalah matriks paska-insiden, yaitu matriks himpunan bobot dari setiap anak panah dari transisi $t$ ke place $p$. Setiap anak panah tersebut hanya memiliki satu arah. Nilai untuk setiap anak panah sebagai komponen matriks pra- dan paska insiden adalah Pre, Post $\in \mathfrak{R} \geq 0^{|P| \times T \mid}$. Dinamika struktur jaringan petri dapat diperoleh dari matriks aliran token (token flow matrix) atau matriks insiden $\boldsymbol{C}=\boldsymbol{P o s t}-\boldsymbol{P r e}$.

Struktur jaring petri $\mathcal{N}$ bersifat statis. Dinamika keadaan struktur jaring Petri secara dinamis dinyatakan dengan $\mathcal{N}=\left\langle\mathcal{N}, \boldsymbol{m}_{\mathbf{0}}\right\rangle$. Vektor $\boldsymbol{m}$ dan $\boldsymbol{m}_{\mathbf{0}}$ adalah vektor jumlah token dan jumlah token awal untuk place $p \in P$ dengan $\boldsymbol{m}, \boldsymbol{m}_{\mathbf{0}} \in$ $\mathbb{R} \geq 0^{|P|}$. Dinamika evolusi token dihasilkan oleh firing. Proses firing dipicu dan diaktifkan oleh kejadian tertentu. Pengaktifan kejadian tertentu (event enabling) untuk transisisi $t_{\mathrm{j}}$ sebelum terjadi firing tergantung fungsi minimal pada persamaan nilai enabling degree (enab) berikut:

$\operatorname{enab}(t, m)=\min _{p \in \bullet_{t}}\left\{\frac{m[p]}{\operatorname{Pre}[\mathrm{p}, \mathrm{t}]}\right\}$

Proses firing dapat terjadi, jika dan hanya jika transisisi dalam kondisi aktif (enabled). Firing pada transisi menghasilkan evolusi token pada himpunan place. Proses evolusi token dapat dibedakan menjadi evolusi token tunggal untuk setiap langkah kejadian firing dan evolusi token gabungan untuk rangkaian firing dari nilai awal token hingga mencapai nilai token tertentu. Evolusi token tunggal pada fireable transisi $t_{\mathrm{j}}$, menghasilkan vektor token baru $m$ ' dari vektor matriks token awal $m_{0}$, dengan persamaaan $m$ ' $=m_{0}+\alpha \mathrm{C}\left(\cdot, t_{\mathrm{j}}\right)$. Nilai token untuk vektor matriks $m_{0}, m^{\prime} \geq 0$.

Untuk mendapatkan TCPN, maka evolusi token dinyatakan sebagai fungsi waktu $\tau$, atau evoluasi dirumuskan sebagai

$m(\tau)=m_{0}+C \cdot \sigma(\tau)$

dengan $\sigma(\tau)$ adalah vektor penghitung firing pada interval $[0, \tau]$. Turunan pertama persamaan (2) terhadap waktu, menghasilkan

$\dot{m}(\tau)=C \cdot \dot{\sigma}(\tau)$

atau ditulis dengan $\dot{m}=C \cdot f$. Menurut Julvez [16] fungsi $f$ dapat dinyatakan sebagai 


$$
f_{j}=\lambda_{j} \cdot \operatorname{enab}\left(t_{j}, m\right)
$$

dimana $\lambda$ disebut internal firing rate suatu transisi. Julvez dkk menegaskan bahwa internal firing rate dapat digunakan untuk menyelesaikan permasalahan konflik yang ada dalam struktur jaring petri.

\section{METODOLOGI}

\subsection{Tahapan Pemodelan}

Secara umum tahapan-tahapan untuk membangun struktur jaring petri untuk sistem energi adalah sebagai berikut:

1. Melakukan pemodelan aliran energi

Tahapan ini adalah tahapan mengidentifikasi aliran energi dari masukan menuju keluaran. Tahapan ini akan memperjelas proses yang berlangsung dan komponen-komponen yang terlibat.

2. Menentukan Interakasi Dengan Lingkungan Tahapan ini untuk memperjelas interaksi sistem dengan lingkungan termasuk pengguna.

3. Membuat diagram aktivitas

Pada tahapan ini dibuat diagram yang menggambarkan proses yang terjadi pada suatu sistem yang akan dimodelkan. Semua kemungkinan aliran energi diperlihatkan dalam diagram ini.

4. Menyederhanakan komponen-komponen sistem

Setelah proses dan komponen-komponen keseluruhan diidentifikasikan, tahapan berikutnya adalah menentukan komponenkomponen sistem yang memiliki memiliki pengaruh yang signifikan atau tidak dalam mengubah kondisi aliran energi. Komponenkomponen yang kurang signifikan disederhanakan.

5. Menentukan kondisi diskrit tiap komponen Komponen-komponen signifikan yang sudah diidentifikasikan pada langkah sebelumnya dianalisis kemungkinan kondisi yang dapat terjadi. Kondisi ini nanti akan dimodelkan dengan struktur petri net dalam bentuk place. Sedangkan faktor-faktor yang dapat mengubah kondisi dimodelkan dengan transisi.

6. Verifikasi model jaring petri

Tahapan terakhir adalah melakukan verifikasi dan validasi hasil.

\subsection{Identifikasi Proses Dan Komponen}

Tahapan pemodelan yang dijelaskan di bagian sebelumnya diaplikasikan untuk sistem ketenagalistrikan skala kecil terisolasi yang tercantum dalam Gambar 1. Diagram aliran energi secara keseluruhan ditampilkan dalam Gambar 3 berikut. Gambar ini menjelaskan bahwa (1) Setelah melalui proses konversi DCDC, pasokan listrik DC dapat mengalir ke beban DC, disimpan di sistem penyimpanan atau dikonversi menjadi listrik AC untuk dipasok ke beban AC, (2) pasokan listrik AC dialirkan untuk memasok beban AC atau dikonversi menjadi listrik DC untuk selanjutnya dipasok ke beban DC.

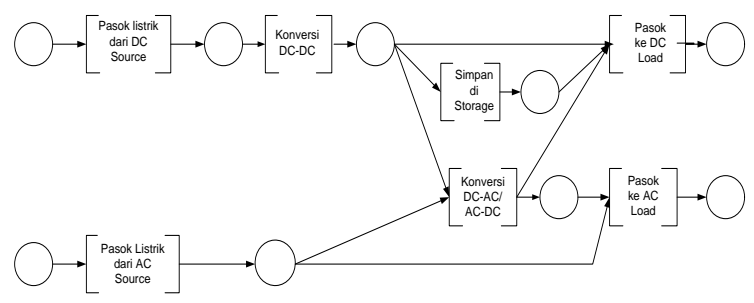

Gambar 3. Grafik Aliran Energi

Dari grafik aliran energi di atas, diidentifikasi komponen-komponen yang signifikan untuk dimodelkan dalam bentuk jaring petri kontinu. Hasil identifikasi adalah sebagai berikut:

1. Pasokan energi listrik DC/AC

Struktur jaring petri kontinu pasokan energi listrik ditampilkan dalam Gambar 4.Token pada place sebelah kanan menunjukkan kondisi pasokan listrik tersedia. Apabila token berada di sebelah kanan menunjukkan kondisi energi listrik dipasok ke sistem. Jumlah token menunjukkan jumlah energi yang tersedia.

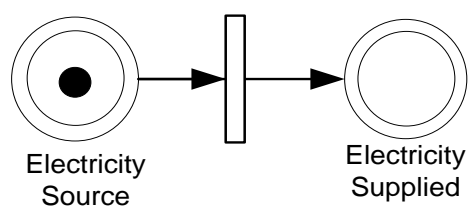

Gambar 4. Jaring Petri Pasokan Listrik

2. Beban listrik DC/AC

Jaring petri beban listrik DC/AC ditampilkan dalam Gambar 5.Dalam gambar ini, jaring petri beban digabungkan dengan pasokan energi listrik. Hal ini untuk memperlihatkan bahwa pasokan listrik ke sistem tidak dapat terjadi apabila tidak ada beban listrik. Beban 
listrik DC/AC dimodelkan dengan satu place. Token pada beban menunjukkan kondisi ada beban listrik.

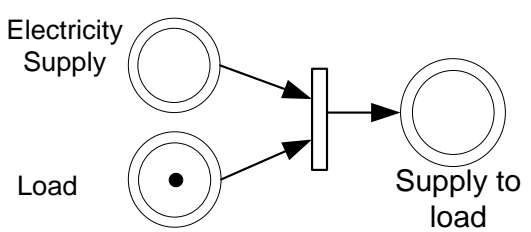

Gambar 5. Jaring Petri Beban dan Pasokan Listrik

3. Penyimpan Listrik DC

Struktur jaring petri kontinu penyimpan energi listrik seperti bateri ditampilkan dalam Gambar 6. Token pada place menunjukkan kondisi penyimpan pasokan listrik penuh. Apabila kondisinya kosong maka token berada di place sebelah kanan.

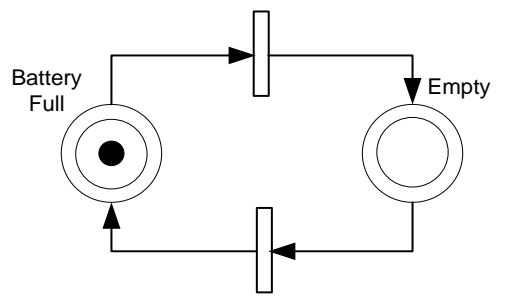

Gambar 6. Jaring Petri Penyimpan Listrik

4. Bidirectional Inverter

Bidirectional Inverter memiliki fungsi dapat mengubah listrik AC menjadi DC atau sebaliknya. Struktur jaring petri kontinu bidirectional Inverter ditampilkan dalam Gambar7.Token pada place di tengah-tengah menunjukkan kondisi inverter menunggu perintah dari pasokan listrik DC atau AC untuk dipasok ke beban DC atau AC.

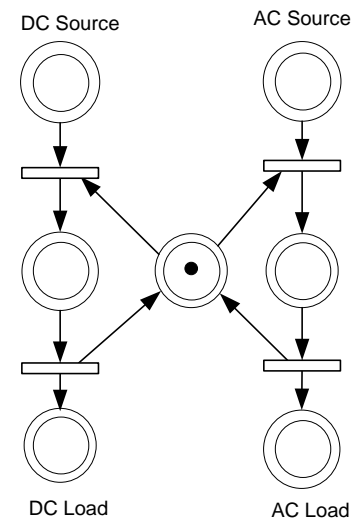

Gambar 7. Jaring Petri Bidirectional Inverter

\section{HASIL DAN PEMBAHASAN}

Untuk menguji model jaring petri yang telah dibuat maka jaring petri kontinu akan disimulasikan menggunakan perangka lunak SimHPN. Ada dua sistem kelistrikan yang akan dimodelkan dan disimulasikan, yaitu:

1. Sistem 1

Sistem terdiri dari satu sumber listrik DC, satu penyimpan dan beban DC seperti ditampilkan dalam Gambar 8 berikut. Tanda panah memperlihatkan aliran energi.

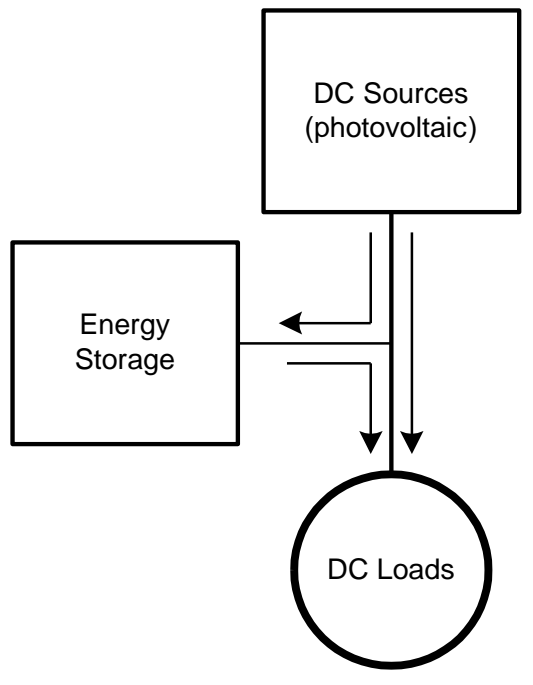

Gambar 8. Aliran Energi Sistem 1

Model jaring petri kontinu sistem 1 ditampilkan dalam Gambar 9 berikut. Dalam gambar ini, $p_{1}$ : place DC source; $p_{2}$ : place DC load; $p_{3}, p_{4}$ : place penyimpan; $p_{5}:$ place kondisi listrik dipasok ke beban. Model sistem 1 memiliki tiga transisi.

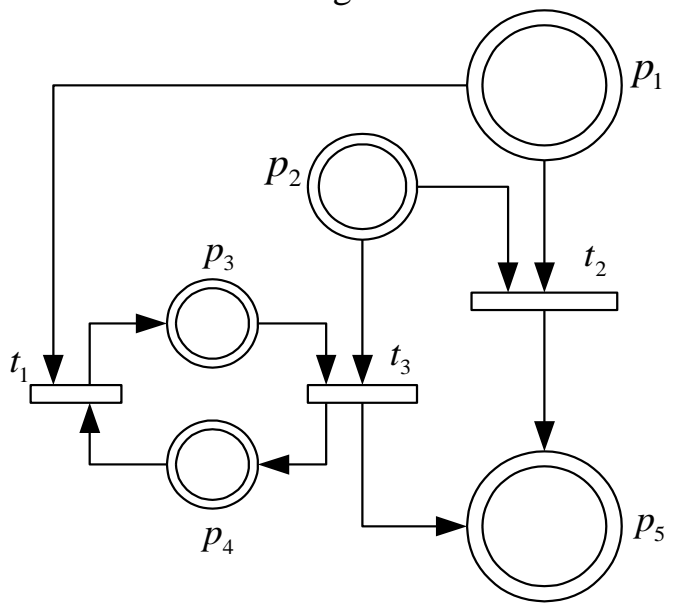

Gambar 9. Jaring Petri Sistem 1 
2. Sistem 2

Sistem terdiri dari satu sumber listrik DC, satu sumber listrik AC, satu penyimpan, satu beban AC,satu beban DC dan satu bidirectional inverter seperti ditampilkan dalam Gambar 10 berikut. Tanda panah memperlihatkan aliran energi.

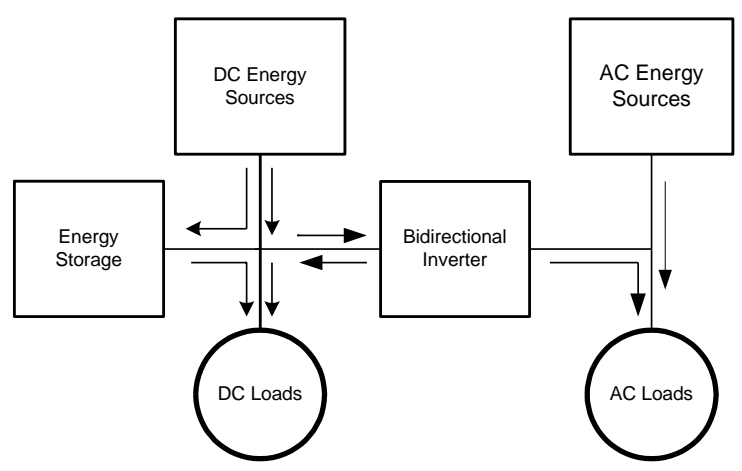

Gambar 10. Aliran Energi Sistem 2

Model jaring petri kontinu sistem 2 ditampilkan dalam Gambar 11 berikut. Dalam gambar ini, $p_{1}$ : place DC source; $p_{2}$ : place DC load; $p_{3}$ : place AC source; $p_{4}$ : place AC load; $p_{5}, p_{6}$ : place penyimpan; $p_{7}$, $p_{8}, p_{9}$ : place bi-directional inverter; $p_{10}$ : place kondisi listrik dipasok ke beban DC; $p_{11}$ : place kondisi listrik dipasok ke beban AC. Model sistem 2 memiliki delapan transisi.

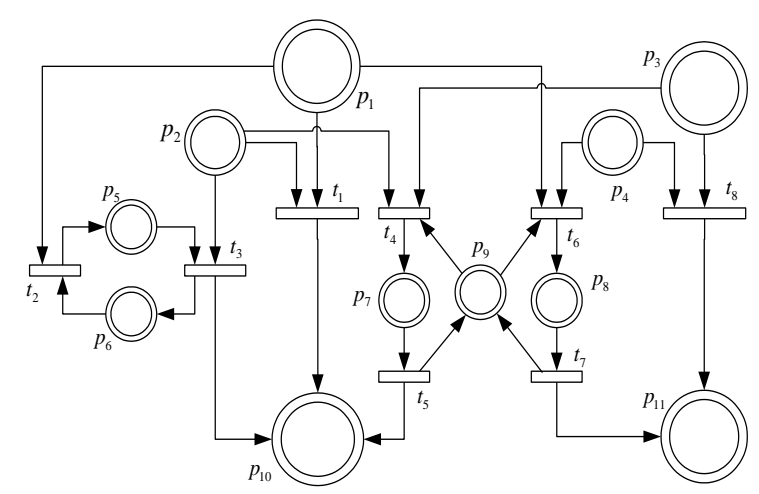

Gambar 11. Jaring Petri Sistem 2

Model jaring petri kontinu di atas disimulasikan menggunakan perangkat lunak SimHPN. Matriks Pre, matriks Post, token awal dan firing rate (lamda) untuk masing-masing sistem dicari dan ditentukan. Simulasi tiap sistem adalah sebagai berikut:

a. Simulasi Sistem 1
Matriks

$$
\text { Pre }=\left[\begin{array}{lll}
1 & 1 & 0 \\
0 & 1 & 1 \\
0 & 0 & 1 \\
1 & 0 & 0 \\
0 & 0 & 0
\end{array}\right] ; \text { Post }=\left[\begin{array}{ccc}
0 & 0 & 0 \\
0 & 0 & 0 \\
1 & 0 & 0 \\
0 & 0 & 1 \\
0 & 1 & 1
\end{array}\right]
$$

Token awal :

$$
m_{0}^{T}=\left[\begin{array}{lllll}
1 & 2 & 1 & 0 & 0
\end{array}\right]
$$

Firing rate :

$\lambda^{T}=\left[\begin{array}{lll}20 & 10 & 5\end{array}\right]$

Hasil simulasi menggunakan SimHPN terlihat pada Gambar 12 . Dari gambar terlihat bahwa token $p_{4}$ dari jumlahnya 0 menjadi 1 , artinya pada akhir simulasi kondisi penyimpan listrik kosong. Hal ini bisa divalidasi dari sistem yang dimodelkan karena kebutuhan beban DC 2 token sedangkan yang dapat disediakan dari DC source hanya satu token sehingga satu token diambil dari penyimpan listrik.

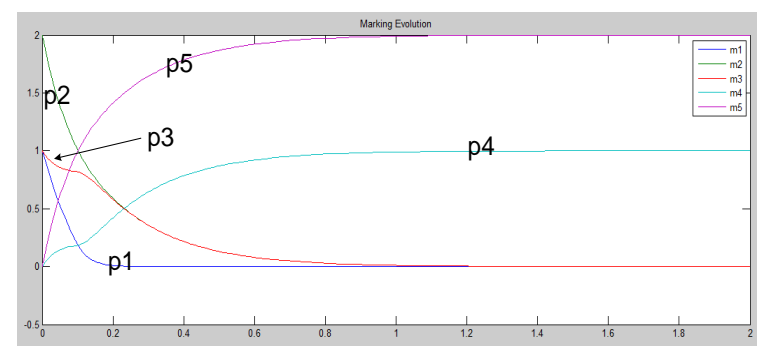

Gambar 12. Evolusi Token Pada Jaring Petri Sistem 1 dengan $m_{0}^{T}=\left[\begin{array}{lllll}1 & 2 & 1 & 0 & 0\end{array}\right]$

Bila kondisi awal token $m_{0}^{T}=\left[\begin{array}{lllll}3 & 2 & 0 & 1 & 0\end{array}\right]$, maka hasil simulasi adalah seperti Gambar 13berikut. Dari gambar terlihat jumlah token $\mathrm{p}_{3}$ (warna merah) berubah dari kosong menjadi 1 , artinya DC source memasok listrik ke penyimpanan listrik.

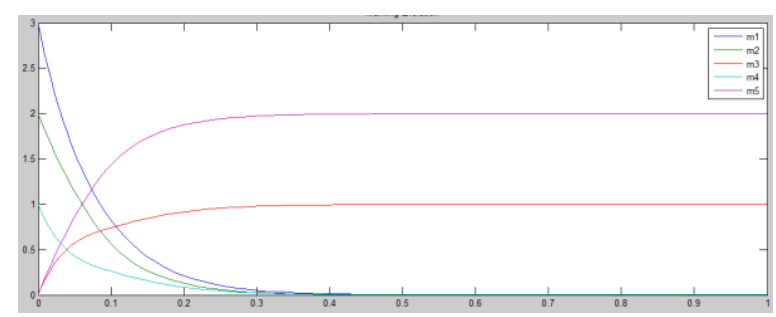

Gambar 13. Evolusi Token Token Pada Jaring Petri Sistem 1 dengan $m_{0}^{T}=\left[\begin{array}{lllll}3 & 2 & 0 & 1 & 0\end{array}\right]$ 
b. Simulasi Sistem 2

Matriks

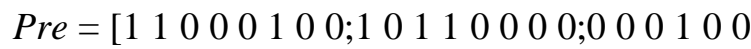

0 1;0000010 1;00100000;0100000

0;00001000;00000010;00010 000 0;0

$000000000 ; 000000000]$

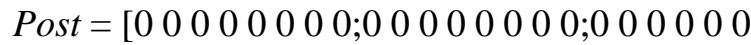

0 0;0000000 0;01000000;0010000

0;00010000;0000010 0;000010 $0010 ; 1$

$0101000 ; 0000000011]$

Token awal $m_{0}:[2 ; 2 ; 2 ; 2 ; 1 ; 0 ; 0 ; 0 ; 1 ; 0 ; 0]$

Firing rate $\lambda:[50 ; 10 ; 1 ; 50 ; 10 ; 50 ; 10 ; 50]$

Hasil simulasi diperlihatkan dalam Gambar 14. Dari gambar, token di $\mathrm{p}_{5}$ tidak mengalami perubahan, begitupula token $\mathrm{p}_{6}$. Ini berarti energi listrik yang tersimpan di penyimpan (bateri) tidak digunakan. Sementara itu berubahnya $\mathrm{p}_{8}$ sesaat menunjukkan bahwa bidirectional inverter telah bekerja untuk memasok listrik ke beban.

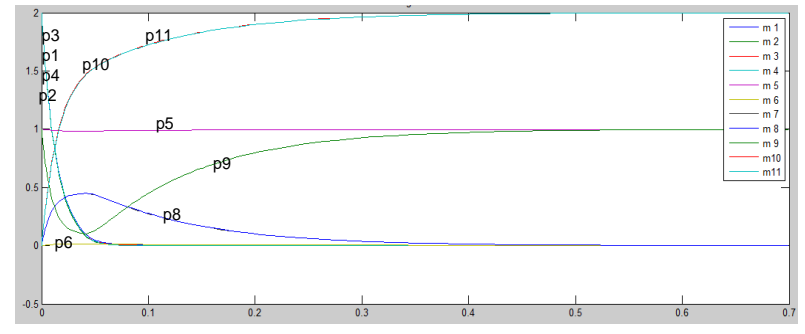

Gambar 14. Evolusi Token Pada Jaring Petri Sistem 2

Dua sistem yang dimodelkan dan disimulasikan adalah model-model dasar yang dapat dikembangkan menjadi model yang lebih kompleks. Tetapi dalam penelitian ini belum dilakukan.

\section{KESIMPULAN}

Dari pembahasan di atas dapat disimpulkan bahwa model Jaring Petri Kontinu Berwaktu yang dikembangkan oleh Julvez dkk dapat diaplikasikan untuk pemodelan sistem ketenagalistrikan skala kecil. Dari hasil simulasi didapat bahwa penentuan nilai Firing rate $\lambda$ mempengaruhi performa dari simulasi. Dalam penelitian ini, model sistem yang dikembangkan masih merupakan model dasar, tetapi model ini dapat dikembangkan untuk sistem ketenagalistrikan yang lebih kompleks.

\section{DAFTAR PUSTAKA}

[1] Draft Rencana Umum Ketenagalistrikan Nasional (RUKN) Kementerian ESDM 2015-2034.

[2] Rencana Strategis Kementerian ESDM 2015-2019.

[3] International Renewable Energy Agency, Innovation Outlook Renewable : MiniGrids, (2016).

[4] International Renewable Energy Agency, Off-Grid Renewable Energy Systems: Status And Methodological Issues (2015).

[5] Abdul Halim, Photovoltaic Power System: Harapan dan kenyataan (Sebuah Studi Di Jepang), Majalah Dimensi Istecs Vol. 4 No. 1 (2001).

[6] Yoshihisa Ishigaki, Yoshitaka Kimura, Ikumi Matsusue, Hidekazu Miyoshi, Kentarou Yamagishi, Optimal Energy Management System for Isolated Micro Grids, SEI Technical Review, No. 78, pp. 73-78 (2014).

[7] Nikos Hatziargyriou, Microgrids Architectures And Control, IEEE Press 2014.

[8] B.C. Wang, M. Sechilariu, F. Locment, Power flow Petri Net modelling for building integrated multi-source power system with smart grid interaction, Mathematics and Computers in Simulation 91, 119-133(2013).

[9] M.P. Fanti, A.M. Mangini, M. Roccotelli, A Petri Net Model for a Building Energy Management System Based on a Demand Response Approach, 22nd Mediterranean Conference on Control and Automation, 816-821 (2014).

[10] Mladjao, M.A.M., Ikram, E.A., AbdelMoumen, D. and Mohammed, E.G., New Robust Energy Management Model for Interconnected Power Networks Using Petri Nets Approach, Smart Grid and Renewable Energy7,46-65 (2016).

[11] J.Júlvez et.al, SimHPN: A MATLAB Toolbox For Simulation, Analysis And Design With Hybrid Petri Nets, Nonlinear Analysis: Hybrid Systems, Vol. 6, No. 2, pp 806-817(2012).

[12] Harjono, M. S., Halim,, A. dan Ramli, A.,Simulation of Improved Hybrid Petri Nets Intersection Model Considering Traffic Distribution, International Journal 
of Soft Computing, Vol. 7, No. 4, p. 217 223 (2012).

[13] Azzumar, M., Halim, A., dan Harjono,M., S. "Performance Evaluation of Two Ways Urban Traffic Control System Based on Macroscopic Hybrid Petri Net Model", International Conference on Advanced Computer Science and Information Systems, Bali, Indonesia (2013).

[14] Mulyadi Sinung Harjono, Wimpie A. N. Aspara, Abdul Halim dan Kalamullah Ramli, Analisis Distribusi Probabilitas Dan Kendali Optimal Persimpangan, Majalah Ilmiah Pengkajian Industri, Vol.9, No.1 (2015).

[15] Rene David, Hassane Alla, Discrete, Continuous and Hybrid Petri Nets, $2^{\text {nd }}$ edition, Springer (2010).

[16] J. Júlvez, R. Boel, A continuous Petri net approach for model predictive control of traffic systems, IEEE Transactions on Systems, Man, and Cybernetics, Part A: Systems and Humans, Vol 40(4), pp. 686697, 2010

\section{Biodata Penulis}

Abdul Halim lulus dari program doktor dari Tokyo Institute of Technology pada tahun 2000. Sejak tahun 2008, bergabung dengan Departemen Teknik Elektro, Universitas Indonesia. Bidang penelitian yang ditekuni adalah pemodelan matematika sistem, kendali optimal. 